\title{
Improving students' self-efficacy and academic performance in Applied Mathematics through innovative classroom-based strategy at Jimma University, Ethiopia
}

\author{
Kinde Getachew and Asfawossen Birhane*
}

doi: http://dx.doi.org/10.18543/tjhe-4(1)-2016pp119-143

\begin{abstract}
Research on area of self efficacy theory is scarce in African context though several scholars propose the need for investigating the practical utility of the theory in other cultural settings aside from Western countries. We have tested the theory of self-efficacy in Ethiopian context and showed how an innovative classroom based strategy (promoting students' mastery experience, exposing students to role model, persuading students the importance of effort and creating favorable attitude towards a subject) influenced self-efficacy belief and academic achievements of students in applied mathematics II employing explanatory sequential mixed methods design. We found statistically significant difference between the experimental group and the control group on mean academic performance of applied math II $(\mathrm{t}=2.75$, $\mathrm{df}=121, \mathrm{p}=.007)$. The magnitude of the mean difference $(\mathrm{MD}=5.77)$ between the two groups was medium $\left(\eta^{2}=.4978\right)$. There was no statistically significant mean difference in the experimental group and the control group on mean score of selfefficacy belief in mathematics $(\mathrm{t}=.626, \mathrm{df}=85, \mathrm{p}=.553)$ though the experimental group scored higher than the control group. We validated the self efficacy theory in Ethiopian context and also provided insight how mathematics instructors could use the innovative classroom based strategy. Further study on the applicability and generalization of the intervention package in other contexts is warranted.
\end{abstract}

Keywords: Self-efficacy; sources of self-efficacy belief; self-efficacy enhancement strategies; mathematics self-efficacy and achievements.

\section{Introduction: Background}

In education context students are expected to invest effort, participate and show perseverance in their learning. However, lack of interest and

* Kinde Getachew Abebe (kinde.getachew@ju.edu.et), MA in Educational Psychology, is associate professor in the Psychology Department at the Jimma University (Ethiopia).

Asfawossen Birhane (basfawesen111@gmail.com), MSc. in Mathematics, is assistant professor in the Mathematics Department at the Jimma University (Ethiopia).

More biographical information is available at the end of this article. 
confidence, low motivation and disengagement are common among students. Such behaviors could be explained by the theory of self-efficacy. ${ }^{1}$ Selfefficacy beliefs determine students academic functioning through cognitive, motivational, affective, and decisional making processes. The cognitive process refers to students thinking in self-enhancing or self-debilitating ways; the motivational aspects includes the motivation students have for their learning and persistence in the face of challenges; the affective domain incorporates emotional aspects of students; and the decision making includes the choices students make in a course of their education. ${ }^{2}$

Students' mathematics self-efficacy is defined as belief of competency in engaging in mathematical problems. ${ }^{3}$ Several scholars indicate students' beliefs in mathematics as an important element in determining their behavior to a large extent $^{4}$. Students with a higher self-efficacy belief display adaptive behavior such as investing the necessary effort, participating eagerly in their learning, recovering from failure more quickly, engaging in challenging learning experiences, discarding quickly a faulty strategy, anticipating higher goals, showing perseverance in the face of difficulty, having motivation to learn, employing different learning strategies, attributing their success to effort and failure to inappropriate strategy than students with low self-efficacy belief. ${ }^{5},{ }^{6}, 8$,

Various research works also demonstrate the relationship between student's self-efficacy belief in mathematics and academic achievement in mathematics.

${ }^{1}$ Del Siegle and Betsy McCoach, "Increasing Student Mathematics Self-Efficacy through Teacher," Journal of Advanced Academics Training 18, no. 2 (2007): 278, doi: 10.4219/jaa-2007-353.

2 Albert Bandura, "Social Cognitive Theory in Cultural Context," Applied Psychology: An International Review 51, no. 2 (2002): 270, doi: 10.1111/1464-0597.00092.

${ }^{3}$ Diana K. May, "Mathematics Self-Efficacy and Anxiety Questionnaire" (PhD Dissertation University Of Georgia, (2009), 1, https://getd.libs.uga.edu/pdfs/may_diana_k_200908_phd.pdf.

${ }^{4}$ Alan Schoenfeld, "Learning to think mathematically: Problem Solving, Metacognition, and Sense-making in Mathematics," in Handbook of Handbook for Research on Mathematics Teaching and Learning, ed. D. Grouws, (New York: MacMillan, 1992), 359.

5 Albert Bandura, "Perceived Self-Efficacy in Cognitive Development and Functioning, Educational Psychologist," Educational Psychologist 28, no. 2 (1993): 144, doi 10.1207/ s15326985ep2802_3.

${ }^{6}$ Albert Bandura, "Social Cognitive Theory," in Annals of Child Development, ed. R. Vasta, Vol.6. Six theories of child development (Greenwich: CT: JAI Press, 1989), 47.

7 Alison Sewell and Alison St George, "Developing Efficacy Beliefs in the Classroom," Journal of Educational Enquiry 1, no. 2 (2000): 59, file:///C:/Users/user/Downloads/5762358-1-PB\%20(6).pdf.

${ }^{8}$ Ahmed Elhassan Hamid Hassan, Abdulaziz Alasmari and Eldood Yousif Eldood Ahmed, "Influences of Self-Efficacy as Predictors of Academic Achievement. A Case Study of Special Education Students- University of Jazan," International Journal of Education and Research 3, no. 3 (2015): 283, ISSN: 2201-6333 (Print) ISSN: 2201-6740 (Online) www.ijern.com. 
The findings reveal students' self-efficacy belief in mathematics influence academic achievement directly or indirectly by raising students' persistence. ${ }^{9}$ Thus, educators need to think of strategies that could enhance student's selfefficacy belief and academic achievement in mathematics. In line with this, a number of researchers suggest self-efficacy theory as a comprehensive model for mathematics teachers for enhancing students' self-efficacy belief and academic achievements through designing appropriate instructional strategies complement with the traditional method of teaching mathematics. ${ }^{10},{ }^{11}$

\section{Statement of the problem}

Despite an increasing number of publications on self-efficacy beliefs and academic performance in math in Western countries over the past decades, researches conducted in the tenet of self-efficacy are bounded by several limitations. Scarce research in African context is one of the limitations though several scholars propose the need for investigating the practical utility of the theory in other cultural settings. ${ }^{12},{ }^{13},{ }^{14}$

In addition, there is little empirical evidence that show how college mathematics instructors enhance students' mathematics self-efficacy in a classroom ${ }^{15},{ }^{16}$ though studies carried out in Western countries suggest instructional strategies involving mastery experiences raise students' mathematics self-efficacy. ${ }^{17},{ }^{18}$

${ }^{9}$ Frank Pajares and David Miller, "Role of Self-Efficacy and Self-Concept Beliefs in Mathematical Problem Solving: A Path Analys," Journal of Educational Psychology 86, no. 2 (1994): 200, http://www.cimm.ucr.ac.cr/.

${ }^{10}$ Ellen, U.L., and Frank Pajares, "Sources of Self-Efficacy in Mathematics: A Validation Study," Contemporary Educational Psychology 34, no. 1 (2009): 100, doi:10.1016/j. cedpsych.2008.09.002.

${ }_{11}$ Amy L. Zeldin, Shari L. Britner, and Frank Pajares, "A Comparative Study of the SelfEfficacy of Successful Men and Women in Mathematics, Science and Technology Careers," Journal of Research in Science Teaching 45, no. 9 (2008): 1054, doi 10.1002/tea.20195.

${ }_{12}$ Tuntufye S. Mwamwenda, "Self-Efficacy and Performance in Mathematics at An African University,"The Journal of Independent Teaching and Learning 4 (2009): 25, http://www.iie.ac.za/.

${ }^{13}$ Siegle and McCoach, "Increasing Student Mathematics Self-Efficacy," 278.

${ }^{14}$ Usher and Pajares, "Sources of Self-Efficacy in Mathematics," 100.

15 Mica A. Hutchison, Deborah K. Follman, Melissa Sumpter, and George M. Bodner, "Factors Influencing the Self-Efficacy Beliefs of First-Year Engineering Students," Journal of Engineering Education 95, no. 1 (2006): 40, doi: 10.1002/j.2168-9830.2006.tb00876.x.

${ }^{16}$ May, "Mathematics Self-Efficacy and Anxiety Questionnaire," 59.

${ }_{17}$ Usher and Pajares, "Sources of Self-Efficacy in Mathematics," 100.

18 Zeldin, Britner and Pajares, "A Comparative Study," 1054. 
On top of that a research work conducted in Ethiopian Universities discloses frustration and low confidence in mathematics among students due to poor background in math, discouragement from instructors when students make mistake, failure to explain concepts adequately as instructors are merely interested to cover chapters, limited time for class activity and poor feedback provision. ${ }^{19}$ Similarly, a study conducted in secondary school students shows significant numbers of students perceive mathematics as a difficult subject to learn and this perception in turn deters students to learn mathematics. ${ }^{20}$ In spite of such problems, there is no single study that gives insight to policy makers and mathematics instructors on how to modify students' sense of self-efficacy belief in a classroom setting and how students' performance could be improved.

In line with the aforementioned gaps, we test the theory of self-efficacy in Ethiopian context and show how the classroom based intervention strategy (promoting mastery experience, exposing students to role model, persuading students the importance of effort and creating favorable attitude towards a subject) influence self-efficacy belief and academic achievements of students in applied math employing explanatory sequential mixed methods design. By doing so, we validate the theory of self efficacy in Ethiopian context in particular, and in Africa in general; and also provide mathematics instructors a viable approach of integrating the intervention strategy with the usual way of instruction. In sum, the study has both theoretical and practical significances. Consequently, we address the following hypothesis.

- $\mathrm{H}_{1}$ : Students who will receive the treatment (self efficacy enhancement strategy) will score higher on self-efficacy belief in applied math II than students who will not receive the treatment $\left(\mathrm{H}_{1}: \mu\right.$ self-efficacy score for the experimental group $\left.\geq \mu_{\text {self-efficacy score for the control group }}\right)$.

- $\mathrm{H}_{1:}$ Students who will expose to the treatment (self efficacy enhancement strategy) will score higher in applied math II academic performance than students who will not expose to the treatment $\left(\mathrm{H}_{1}: \mu\right.$ for the experimental group $\geq \mu$ academic achievements for the control group $)$.

19 Asfawossen B. and Kinde G, "Gender, Self-Efficacy Belief, Sources of Self-Efficacy Associated to Academic Achievements in Applied Mathematics: The Case of First Year Engineering Students of South Western Universities Of Ethiopia," International Journal of Current Research 8 no. 05 (2016): 30398, http://www.journalcra.com/.

${ }^{20}$ Tesfaye Jale Geche, "Learning Styles and Strategies of Ethiopian Secondary School Students in Learning Mathematics" (Master Thesis, University of South Africa, 2009), 80, http://hdl.handle.net/10500/3125. 


\section{Theoretical framework}

\section{III.1. Self-efficacy theory}

In an attempt to study and influence students' academic engagement, one could not think a better theory than Bandura's theory of self-efficacy as it is a well tested theory, suggests ways of improving educational practices and scores of researchers have also shown the effectiveness of the various intervention programs based on the theory. ${ }^{21},{ }^{22},{ }^{23}$ The theory clearly articulates the constructs of self-efficacy and also posits how self-efficacy could be formed and modified in a classroom level. According to self efficacy theory, students' self-efficacy is developed as students interpret their exposure with respect to mastery experiences, vicarious experiences, verbal persuasion and physiological and emotional arousal. $.^{24},{ }^{25}$

Performance/mastery accomplishment is the experience students perceived from a specific activity in the past; and successful performance of the activity enhances a sense of self-efficacy while unsuccessful accomplishments wakened the formation of self-efficacy belief ${ }^{26}{ }^{27}$ Performance experience is the very important aspect of self-efficacy belief and contributes a lot for students' selfefficacy belief and academic achievements. If students have a history of good performance in a certain subject, then they will develop belief that they will be a good performer in that particular subject in the future $.^{28},^{29}$ Performance experiences could be enhanced in the classroom by breaking complex behavior to small achievable goals; establishing small goals; making an individual's effort and recording progress with a calendar..$^{30}$

${ }^{21}$ Artino Anthony, "Academic Self-Efficacy: From Educational Theory to Instructional Practice," Journal of Perspectives on Medical Education 1, no. 2 (2012): 81, doi: 10.1007/ s40037-012-0012-5.

${ }^{22}$ Ellen L. Usher and Frank Pajares, "Sources of Academic and Self-Regulatory Efficacy Beliefs of Entering Middle School Students," Contemporary Educational Psychology 31, (2006): 125, doi:10.1016/j.cedpsych.2005.03.002.

${ }^{23}$ Mart van Dinther, Filip Dochy and Mien Segers, "Factors affecting students' selfefficacy in higher education," Educational Research Review 6, no. 2 (2011): 104, doi:10.1016/j. edurev.2010.10.003.

${ }^{24}$ Zeldin, Britner, and Pajares, "A Comparative Study," 1037.

${ }^{25}$ Barry J. Zimmerman, "Self-Efficacy: An Essential Motive to Learn," Contemporary Educational Psychology 25 (2000): 88, doi:10.1006/ceps.1999.1016.

${ }^{26}$ Zeldin, Britner, and Pajares, "A Comparative Study," 1037.

${ }^{27}$ Zimmerman, "Self-Efficacy: An Essential Motive to Learn," 88.

${ }^{28}$ Usher and Pajares, "Sources of Self-Efficacy in Mathematics," 100.

29 Zeldin, Britner and Pajares, “A Comparative," 1037.

${ }^{30}$ Siegle and McCoach, "Increasing Student Mathematics Self-Efficacy," 284. 
The other source of self-efficacy belief is vicarious experiences. Vicarious experiences serve as an important function as a role model in which observing a student succeeded or failed in a particular subject could likely alter other students' self-efficacy beliefs in that particular subject. ${ }^{31}$ Usher and Pajares state that if students observe a classmate succeed in a challenging mathematics problem, for example, they would be likely convinced that they could also master the challenging task. ${ }^{32}$

Verbal persuasion which includes encouragement from parents, teachers, and peers is one sources of self-efficacy-belief; and the physiological arousal that includes anxiety, stress, fatigue, and mood is also other sources of selfefficacy-belief. Encouragement from parents, teachers, and peers whom students trust can boost students' confidence in their academic capabilities; and also promoting students' positive emotional state and reducing negative emotional experiences strengthens self-efficacy. ${ }^{33}$ However, various research works have shown that these two sources of self-efficacy belief contribute the least to self-efficacy belief formation. ${ }^{34}$

\section{III.2. Intervention packages}

Various research works have shown that teachers could cultivate and promote students' self-efficacy and academic achievements based on four sources of self-efficacy belief. ${ }^{35},{ }^{36},{ }^{37},{ }^{38}$ In the process of modifying students' sense of self-efficacy belief and academic achievements, instructors could integrate the usual method of instruction with self efficacy enhancement strategy. ${ }^{39}$ Brewer writes as follow how to integrate an innovative pedagogy with the existing traditional instruction:

31 Zeldin, Britner and Pajares, “A Comparative Study of the Self- Efficacy,” 1037.

${ }_{32}$ Usher and Pajares, "Sources of Self-Efficacy in Mathematics," 89.

${ }^{33}$ Ibid., 90.

34 Zeldin, Britner and Pajares, “A Comparative Study of the Self- Efficacy,” 1037.

${ }^{35}$ Usher and Pajares, "Sources of Self-Efficacy in Mathematics," 100.

${ }_{36}$ Siegle and McCoach, "Increasing Student Mathematics Self-Efficacy," 280.

37 C.W.Loo and J.L.F. Choy, "Sources of Self-Efficacy Influencing Academic Performance of Engineering Students," American Journal of Educational Research 1, no. 3 (2013): 91 DOI: 10.12691/education-1.

${ }^{38}$ Meera K.P. and Jumana M. K "Self-Efficacy and Academic Performance In English" Imperial Journal of Interdisciplinary Research, 2, no. 2 (2016): 83. ISSN: 2454-1362, http:// www .onlinejournal.in

39 Zeldin, Britner, and Pajares, “A Comparative Study of the Self-Efficacy,” 1054. 
The traditional framework of most college algebra classes includes lectures provided by the instructor and homework completed by the student. If effective pedagogical changes made that fit within this traditional lecturebased framework then it is more likely that these changes will be accepted and consistently used by the collegiate mathematics education community. ${ }^{40}$

Consequently, we develop an innovative classroom based strategy that could enhance students' self efficacy belief and academic achievements in mathematics. It is innovative because we align the self-efficacy enhancement strategy with lecturing and implement the intervention regularly during instruction. The innovative classroom based strategy is basically adapted from Bandura's theory of self-efficacy and existing literatures. ${ }^{41}$ There are lots of practical and theoretical evidences that show the effectiveness of the innovative classroom based strategy in influencing students' self-efficacy belief and academic achievements in mathematics. ${ }^{42}{ }^{43}$

We hypothesize that a combination of the innovative classroom based strategy with the traditional instruction is likely to have an influence in students' academic achievements and self-efficacy belief in math II as depicted in figure 1 .

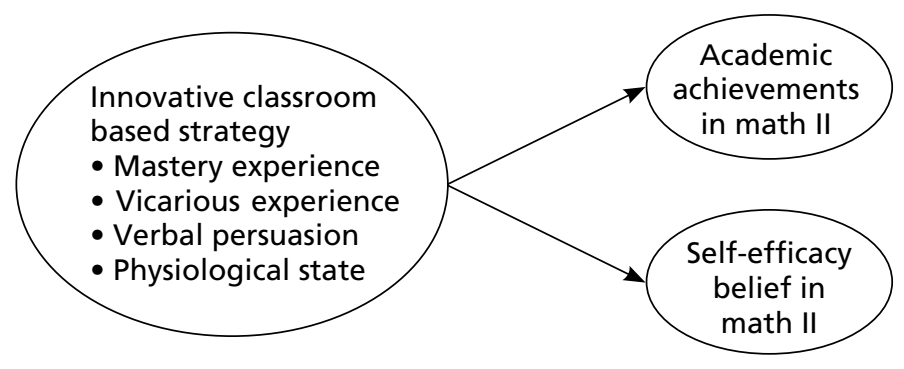

Figure 1

Schematic diagram of the innovative classroom based strategy and proposed influence on students' academic achievements and self-efficacy belief in math II

${ }^{40}$ David, Shane Brewer, "The Effects of Online Homework on Achievement and Selfefficacy of College Algebra Students" (Dissertations Thesis, Utah State University, 2009), 2, Paper 407, http://digitalcommons .usu .edu/etd/407.

${ }^{41}$ Siegle and McCoach, "Increasing Student Mathematics Self-Efficacy," 283.

${ }^{42}$ Usher and Pajares, "Sources of Academic and Self-Regulatory Efficacy Beliefs," 140.

${ }^{43}$ Siegle and McCoach, "Increasing Student Mathematics Self-Efficacy," 306. 
Instructors implement the innovative classroom based strategy along with the daily traditional instruction in mathematics. The elements of the innovative classroom based strategy are depicted in table 1 .

Table 1

Elements of the innovative classroom based strategy

\begin{tabular}{|c|c|}
\hline Strategies & When to implement \\
\hline \multicolumn{2}{|l|}{ Strategy 1: Mastery experience } \\
\hline Starting the lesson with a review & beginning of lesson \\
\hline $\begin{array}{l}\text { Posting the daily lesson objective or shared them } \\
\text { with the student }\end{array}$ & beginning of lesson \\
\hline Reviewing and checking objectives achieved & at the end of the lesson \\
\hline $\begin{array}{l}\text { Asking students to record each day on a calendar } \\
\text { something new they learned }\end{array}$ & at the end of the lesson \\
\hline $\begin{array}{l}\text { Reinforcing students (could be privately or in } \\
\text { group) on the objectives they had mastered }\end{array}$ & $\begin{array}{l}\text { always, during or after } \\
\text { lesson }\end{array}$ \\
\hline $\begin{array}{l}\text { Writing a specific feedback on assignment, class } \\
\text { work }\end{array}$ & $\begin{array}{l}\text { always, during or after } \\
\text { lesson }\end{array}$ \\
\hline $\begin{array}{l}\text { Prompting students who perform poorly to } \\
\text { attribute their failures to lack of effort }\end{array}$ & $\begin{array}{l}\text { always, during or after } \\
\text { lesson }\end{array}$ \\
\hline $\begin{array}{l}\text { Completing accomplishment plan by setting up } \\
\text { small goals and proceed to difficult ones }\end{array}$ & $\begin{array}{l}\text { always, during or after } \\
\text { lesson }\end{array}$ \\
\hline $\begin{array}{l}\text { Helping students to record goals achieved for } \\
\text { the accomplishment plan }\end{array}$ & $\begin{array}{l}\text { always, during or after } \\
\text { lesson }\end{array}$ \\
\hline Reviewing student's accomplishment plan & all the time \\
\hline \multicolumn{2}{|l|}{ Strategy 2: Vicarious experiences } \\
\hline Peer modeling & $\begin{array}{l}\text { beginning of the } \\
\text { intervention }\end{array}$ \\
\hline \multicolumn{2}{|l|}{ Strategy 3: Verbal persuasion } \\
\hline $\begin{array}{l}\text { Encouraging students' performance or ability to } \\
\text { perform }\end{array}$ & all the time \\
\hline $\begin{array}{l}\text { Orienting students continuously they could master } \\
\text { applied II with an effort }\end{array}$ & all the time \\
\hline \multicolumn{2}{|l|}{ Strategy 4: Emotional arousal } \\
\hline $\begin{array}{l}\text { Comforting students during exercise, exam, telling } \\
\text { them the type of exam }\end{array}$ & $\begin{array}{l}\text { Whenever there is } \\
\text { exercise, test }\end{array}$ \\
\hline
\end{tabular}




\section{Methodology}

\section{IV.1. Design of the intervention phase}

An explanatory sequential mixed methods design was used as indicated in figure 2. First, a quasi-experimental design was used followed by a qualitative method. The quasi-experimental design was chosen because it was not possible to randomly assign students to either the treatment or the control group as the group (classroom) was already formed.$^{44}$ Researchers in the area of selfefficacy suggest that a quantitative study should be complemented by qualitative inquiry to get additional information. ${ }^{45}$ Thus, we conducted FGDs with some students of experimental group at the conclusion of the intervention to document their experience in applied math II before the intervention, change in self-efficacy, academic achievements, positive and negative aspect of the intervention. The study was conducted over four week periods in the second semester of 2015/16 academic year, in 123 (90 males, 33 females) first year engineering students, Institute of Technology, Jimma University, Ethiopia.

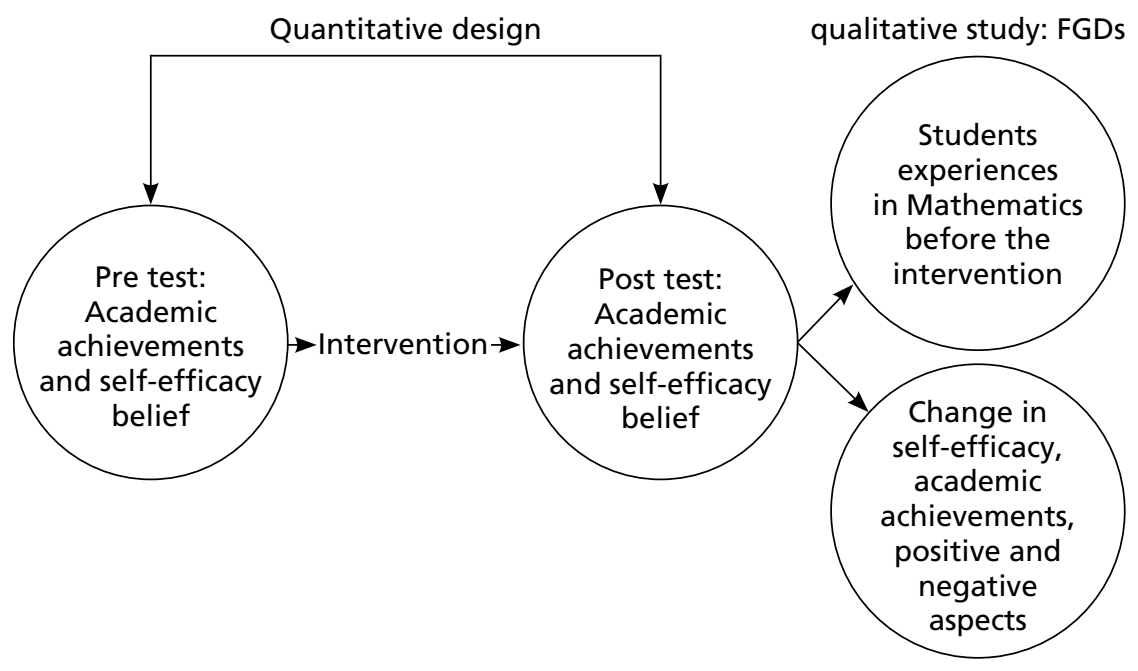

Figure 2

Explanatory sequential mixed methods design

${ }^{44}$ John W. Creswell, Educational Research: Planning, Conducting, and Evaluatin Quantitative and Qualitative Research (Boston: Pearson,2012), 309.

45 Zeldin, Britner, and Pajares, “A Comparative Study of the Self-Efficacy,” 1037. 


\section{IV.2. Instruments}

Self-efficacy belief: A scale on self-efficacy measure was used to measure students' level of self-efficacy belief in mathematics before and after the experiment. The self-efficacy scale contains 14 items which was adapted to suit mathematics self-efficacy for college students. Students rate each item on a five point scale (1-Never; 2-Seldom; 3-Sometimes; 4-Often; 5-Usually). As an example, 'I feel confident to ask questions in my applied mathematics class', 'I believe I can do well on applied mathematics test' and 'I believe I can understand the content in applied mathematics course' were some of the items included in the self-efficacy scale. ${ }^{46}$ The psychometric qualities of the self-efficacy were checked taking 25 first year material engineering students from Jimma University, Technology Institute. The Chronbach alpha ( $\alpha$ level) inter item reliability estimate was .961 .

Mathematics Achievement II: Mathematics achievement was operationalized as a numerical grade students received on mid and final exams of applied math II. The academic achievement tests were developed in relation with the course outline of applied mathematics II by the classroom teacher. Students' score in the mid exam was served as a pretest and the final exam was served as a post test. The psychometric quality, especially the content validity of the exams, was checked.

Intervention Package: An intervention package was adapted, piloted and used for the study. The intervention package was tried out in first year material engineering students. We learnt from the pilot test the intervention packages could be implemented in a classroom with some preparation. Some strategies were excluded from the final intervention. For instance, peer modeling by senior students was excluded as it was difficult to arrange.

FGDs: Students' experiences in mathematics before and after the intervention and possible changes in self-efficacy and academic achievements as result of the intervention, positive and negative aspect of the intervention were probed.

\section{IV.3. Procedures}

First, among applied mathematics course instructors who were offering the applied mathematics II in the 2015/16 in Jimma University, Institute of Technology, one instructor was selected. The criteria for the selection was

46 May, "Mathematics Self-Efficacy and Anxiety Questionnaire," 72. 
teaching at least two sections as they serve as the control and experimental groups, had some training on method of teaching and experienced in teaching applied mathematics II. Students of one department were assigned in a control group while students of the other department were assigned in the experimental group randomly.

Then, orientation to the selected instructor was given for about an hour by the investigators on how to go about the whole experiment. Specifically, detailed orientation was given with the help of an intervention guideline. The orientation was focused on how to do each component of the intervention packages, when to do the various components and also how to effectively engage students in the some component of the strategy. Moreover, the instructor was told to register the strengths, weaknesses, unusual or unexpected circumstances during the intervention and write any comments of the experiment on the prepared guidelines throughout the intervention phase. Each day the instructor recorded the self-efficacy strategies implemented during the instruction in a checklist. The instructor also oriented how to engage students effectively in mathematics instruction with the help of student accomplishment plan and a calendar. The orientation was focused on how students should use the plan and the calendar in applied math II.

At the onset of the experiment, students were given a brief description of the procedure and asked whether they were willing to participate and no one refused. Then, a pre test was conducted and compared to see whether the experimental and control group were equivalents on their level of mathematics self-efficacy scores and on their midterm exam achievements on applied math II. With this the researchers checked the equivalence of the two groups on self-efficacy measure and academic achievements scores at the onset.

There were 63 students in the experimental group and 60 students in the control group. Students in the experimental group were taught applied math II with instructional strategies containing self-efficacy intervention management for about 4 weeks ( 3 hours per week) by the classroom teacher while students in the control group were taught with the usual instruction. The actual implementation of the mastery, vicarious, verbal and emotional experiences were $86 \%, 100 \%, 93 \%$ and $86 \%$ as depicted in table 2 , respectively.

Then, a self-efficacy scale similar to the pre test and a final exam on applied mathematics II were administered for the experimental and control groups at the conclusion of the intervention. Finally, experimental group's self-efficacy and academic achievement scores in applied math II were compared to the control group. Moreover, FGD with students was conducted to secure additional information on changes of self-efficacy belief, academic achievements and the whole process of the intervention. 
Table 2

Actual performance of the intervention packages

\begin{tabular}{|c|c|c|c|c|c|c|c|c|}
\hline \multirow[b]{2}{*}{ Strategies } & \multicolumn{2}{|c|}{ Week 1} & \multicolumn{2}{|c|}{ Week 2} & \multicolumn{2}{|c|}{ Week 3} & \multirow{2}{*}{$\begin{array}{c}\text { Week } 4 \\
1^{\text {st }} \\
\text { class }\end{array}$} & \multirow{2}{*}{$\begin{array}{l}\text { Achieved } \\
(\%)\end{array}$} \\
\hline & $\begin{array}{c}1^{\text {st }} \\
\text { class }\end{array}$ & $\begin{array}{l}2^{\text {nd }} \\
\text { class }\end{array}$ & $\begin{array}{c}1^{\text {st }} \\
\text { class }\end{array}$ & $\begin{array}{l}2^{\text {nd }} \\
\text { class }\end{array}$ & $\begin{array}{c}1^{\text {st }} \\
\text { class }\end{array}$ & $\begin{array}{c}2^{\text {nd }} \\
\text { class }\end{array}$ & & \\
\hline \multicolumn{9}{|c|}{ Strategy 1 (Mastery experiences) } \\
\hline $\begin{array}{l}\text { Starting the lesson } \\
\text { with a review }\end{array}$ & $x$ & $x$ & $x$ & $x$ & $x$ & $\mathrm{x}$ & $x$ & $100 \%$ \\
\hline $\begin{array}{l}\text { Posting the daily } \\
\text { lesson objective }\end{array}$ & $x$ & $x$ & $x$ & $x$ & $x$ & $x$ & $x$ & $100 \%$ \\
\hline $\begin{array}{l}\text { Reviewing and } \\
\text { checking objectives }\end{array}$ & $\mathrm{x}$ & $x$ & $x$ & $x$ & $x$ & $x$ & $x$ & $100 \%$ \\
\hline $\begin{array}{l}\text { Asking students to } \\
\text { record each day on a } \\
\text { calendar something } \\
\text { new they learned }\end{array}$ & $\mathrm{x}$ & $x$ & $x$ & $x$ & $x$ & $x$ & $x$ & $100 \%$ \\
\hline $\begin{array}{l}\text { Reinforcing students } \\
\text { (could be privately or } \\
\text { in group) }\end{array}$ & & $x$ & $x$ & & & $x$ & $x$ & $71 \%$ \\
\hline $\begin{array}{l}\text { Writing a specific } \\
\text { feedback on } \\
\text { assignment, class } \\
\text { work }\end{array}$ & $x$ & $x$ & & $x$ & $x$ & & $x$ & $71 \%$ \\
\hline $\begin{array}{l}\text { Prompting students } \\
\text { who perform poorly } \\
\text { to attribute their } \\
\text { failures to lack of } \\
\text { effort }\end{array}$ & $x$ & $x$ & $x$ & & $x$ & $x$ & $x$ & $86 \%$ \\
\hline $\begin{array}{l}\text { Completing } \\
\text { accomplishment plan }\end{array}$ & $x$ & $x$ & $x$ & $x$ & $x$ & $x$ & $x$ & $100 \%$ \\
\hline $\begin{array}{l}\text { Helping students } \\
\text { to record goals } \\
\text { achieved }\end{array}$ & & & & & $x$ & $x$ & $x$ & $29 \%$ \\
\hline $\begin{array}{l}\text { Reviewing student's } \\
\text { accomplishment plan }\end{array}$ & $x$ & $x$ & $x$ & $x$ & $x$ & $x$ & $x$ & $100 \%$ \\
\hline \multicolumn{9}{|c|}{ Strategy 2 (Vicarious experiences) } \\
\hline Peer modelling & $x$ & & & & & & & $100 \%$ \\
\hline
\end{tabular}




\begin{tabular}{|c|c|c|c|c|c|c|c|c|}
\hline \multirow[b]{2}{*}{ Strategies } & \multicolumn{2}{|c|}{ Week 1} & \multicolumn{2}{|c|}{ Week 2} & \multicolumn{2}{|c|}{ Week 3} & \multirow{2}{*}{$\begin{array}{c}\text { Week } 4 \\
1^{\text {st }} \\
\text { class }\end{array}$} & \multirow{2}{*}{$\begin{array}{c}\text { Achieved } \\
(\%)\end{array}$} \\
\hline & $\begin{array}{c}1^{\text {st }} \\
\text { class }\end{array}$ & $\begin{array}{c}2^{\text {nd }} \\
\text { class }\end{array}$ & $\begin{array}{c}1^{\text {st }} \\
\text { class }\end{array}$ & $\begin{array}{l}2^{\text {nd }} \\
\text { class }\end{array}$ & $\begin{array}{c}1^{\text {st }} \\
\text { class }\end{array}$ & $\begin{array}{l}2^{\text {nd }} \\
\text { class }\end{array}$ & & \\
\hline
\end{tabular}

\section{Strategy 3 (Verbal persuasion)}

\begin{tabular}{|c|c|c|c|c|c|c|c|c|}
\hline $\begin{array}{l}\text { Encouraging } \\
\text { pertaining } \\
\text { to students' } \\
\text { performance }\end{array}$ & $x$ & $x$ & $x$ & $x$ & $x$ & $x$ & $x$ & $100 \%$ \\
\hline $\begin{array}{l}\text { Orienting students } \\
\text { continuously that } \\
\text { they could master } \\
\text { applied II with an } \\
\text { effort }\end{array}$ & & $x$ & $x$ & $x$ & $x$ & $x$ & $x$ & $86 \%$ \\
\hline \multicolumn{9}{|c|}{ Strategy 4 (Emotional arousal) } \\
\hline $\begin{array}{l}\text { Comforting students } \\
\text { during exercise, exam }\end{array}$ & $x$ & & $x$ & $x$ & $x$ & $x$ & $x$ & $86 \%$ \\
\hline
\end{tabular}

\section{IV.4. Analysis}

\section{IV .4.1. Quantitative Analysis}

Mean and independent t test were used to check differences on mathematics self-efficacy and academic achievement scores of applied Mathematics II between the control and experimental groups before and after the intervention. A two tail $\mathrm{t}$ test with $.05 \alpha$ level was used.

\section{IV .4.2. Qualitative analysis}

Qualitative data analysis was conducted by transcribing and coding key data elements. Then, codes were merged to thematic areas.

\section{IV .5. Ethical Considerations}

Permission was obtained from each participant. The aim of the study was explained to the respondents and confidentiality was assured using code instead of names throughout the research. 


\section{Results}

60(48 males, 12 females) and 63(42 males, 21 females) students participated in the control and experimental group, respectively. The mean age of the participants was 19.47 with a standard deviation of 1.28 .

\section{V.1. Difference on self-efficacy scores between the experimental and control groups before the intervention}

The mean score on self-efficacy belief in mathematics for the experimental group was 3.62 with a standard deviation of .81 while the mean score on selfefficacy belief in mathematics for the control group was 3.58 with a standard deviation of .77 .We run independent $t$ test to check the observed differences on measure of self-efficacy belief in mathematics between the control and experimental group were statistically significant. The Shapiro-Wilk test indicated that the assumption of normality was met for the experimental (statistic $=.978, \mathrm{df}=47, \mathrm{p}=.508)$ and the control (statistic $=.984, \mathrm{df}=43$, $\mathrm{p}=.813$ ) groups. The independent sample $\mathrm{t}$ test indicated there was no statistically significant mean differences in the two groups on mean scores of self-efficacy belief in mathematics $(\mathrm{t}=.252, \mathrm{df}=88, \mathrm{p}=.802)$.

\section{Table 3}

Mean scores on self-efficacy beliefs in mathematics between the experimental and control groups before the intervention

\begin{tabular}{|l|c|c|c|c|c|}
\hline \multicolumn{1}{|c|}{ Groups } & $\bar{X}$ & $\mathrm{SD}$ & $\mathrm{df}$ & $\mathrm{t}$ & $\mathrm{P}$ \\
\cline { 1 - 4 } Experimental group & 3.62 & .811 & \multirow{2}{*}{85} & \multirow{2}{*}{.252} & \multirow{2}{*}{.802} \\
\cline { 1 - 3 } Control group & 3.58 & .773 & & & \\
\hline
\end{tabular}

\section{V.2. Differences on self-efficacy scores between the experimental and control groups after the intervention}

The mean scores on self-efficacy belief in mathematics for the experimental group was 3.67 with a standard deviation of .663 while the mean score for self-efficacy belief in mathematics for the control group was 3.57 with a standard deviation of .773 . We conducted independent $t$ test to check the observed differences on measure of self-efficacy belief in mathematics between the experimental and control groups were statistically 
significant. The Shapiro-Wilk test indicated that the assumption of normality was met for the experimental (statistic $=.967, \mathrm{df}=44, \mathrm{p}=.234$ ) and the control (statistic $=.984, \mathrm{df}=43, \mathrm{p}=.813$ ) groups. Though the experimental group scored higher than the control group on measure of self-efficacy belief in mathematics, the independent sample $t$ test indicated there was no statistically significant mean differences between the experimental and the control groups $(\mathrm{t}=.626, \mathrm{df}=85, \mathrm{p}=.553)$.

Thus we failed to reject $\mathrm{H}_{\mathrm{o}}$ as students who received the treatment in experimental group did not exhibit a statistically significant mean difference on measure of self-efficacy beliefs in mathematics compared to students who were assigned in the control group $\left(\mathrm{H}_{0}: \mu\right.$ self-efficacy score for the experimental group $=\mu$ self-efficacy score for the control group).

\section{Table 4}

Mean score on self-efficacy belief in mathematics between the experimental and control groups after the intervention

\begin{tabular}{|l|c|c|c|c|c|}
\hline \multicolumn{1}{|c|}{ Groups } & $\bar{X}$ & SD & df & $\mathrm{t}$ & $\mathrm{P}$ \\
\hline Experimental group & 3.67 & .663 & \multirow{2}{*}{85} & .626 & .533 \\
\cline { 1 - 3 } Control group & 3.57 & .773 & & & \\
\hline
\end{tabular}

\section{V.3. Differences on academic achievements in applied math II between the experimental and control groups before the intervention}

The mean scores on academic performance in applied mathematics II for students of the experimental and control groups were computed before the intervention to check their equivalence. The mean academic performance (Mean $=13.06$, Std. dev. $=6.485)$ of students in the experimental group was higher than the mean academic performance (Mean $=12.00$, Std. dev. $=6.344$ ) of the control group. We run independent $t$ test to check the observed differences on mid academic performance of applied math II between the experimental and the control groups were statistically significant. The Shapiro-Wilk test indicated that the assumption of normality was met for the experimental (statistic $=.090, \mathrm{df}=63, \mathrm{p}=.200$ ) and the control (statistic $=.986$, $\mathrm{df}=60, \mathrm{p}=.061)$ groups. The independent sample $\mathrm{t}$ test indicated there was not a statistically significant differences on mean scores of mid academic performances of applied math II $(\mathrm{t}=.905, \mathrm{df}=121, \mathrm{p}=.336)$ between the experimental and the control groups. Prior to the intervention both groups of students had similar academic performances in applied mathematics II. 


\section{Table 5}

Mean scores on academic performances in applied mathematics II for the experimental and control groups before the intervention

\begin{tabular}{|l|c|c|c|c|c|}
\hline \multicolumn{1}{|c|}{ Groups } & $\bar{X}$ & SD & df & $t$ & $\mathrm{P}$ \\
\hline Experimental group & 13.06 & 6.485 & \multirow{2}{*}{121} & .905 & .336 \\
\cline { 1 - 3 } Control group & 12.00 & 6.345 & & & \\
\hline
\end{tabular}

V.4. Differences on academic achievements in applied math II between the experimental and control groups after the intervention

The mean academic performance $($ Mean $=23.96$, Std. dev. $=10.08)$ of students in the experimental group was higher than the mean academic performance $($ Mean $=18.19$, Std. dev. $=13.06)$ of students who were assigned in the control group. The Shapiro-Wilk test indicated the assumption of normality was met for the experimental ( statistic $=.985, \mathrm{df}=63, \mathrm{p}=.658$ ) and the control (statistic $=.964, \mathrm{df}=60, \mathrm{p}=.132$ ) groups on mean academic performance of applied math II. Then, we run independent $t$ test to check the observed differences on mean academic performance of applied math II between the experimental and the control groups were statistically significant. The independent sample $t$ test indicated there was statistically significant differences between the experimental and the control groups on mean academic performances of applied math $\mathrm{II}(\mathrm{t}=2.75, \mathrm{df}=121, \mathrm{p}=.007)$. The magnitude of the mean difference $(\mathrm{MD}=5.77)$ between the two groups was medium $\left(\eta^{2}=.4978\right)$.

Thus, we rejected $\mathrm{H}_{0}$ as students in the experimental group had a statistically significant mean differences in academic achievements in applied mathematics II compared to students who were assigned in the control group $\left(\mathrm{H}_{0}: \mu\right.$ academic performance for the experimental group $=\mu$ academic performance for the control group).

Table 6

Mean scores on academic performances in applied mathematics II for the experimental and control groups after the intervention

\begin{tabular}{|l|c|c|c|c|c|}
\hline \multicolumn{1}{|c|}{ Groups } & $\bar{X}$ & SD & df & t & P \\
\cline { 1 - 3 } Experimental group & 23.96 & 10.08 & \multirow{2}{*}{121} & 2.75 & .007 \\
\cline { 1 - 3 } Control group & 18.19 & 13.06 & & & \\
\hline
\end{tabular}


The pre-test and pos-test mean scores on academic achievements in applied math II for the experimental and control groups were graphed as follow. As shown in the figure, the progress of the experiment and the control groups follow a different pattern. In this regard, it could be concluded that exposing students to the innovative classroom based strategy resulted in different effects of academic performances in applied mathematics II. More specifically, the experimental group had higher gains in terms of academic performance in applied mathematics II at the post test than the control group even though they were nearly equal at the pre test. This situation is illustrated in the graph below.

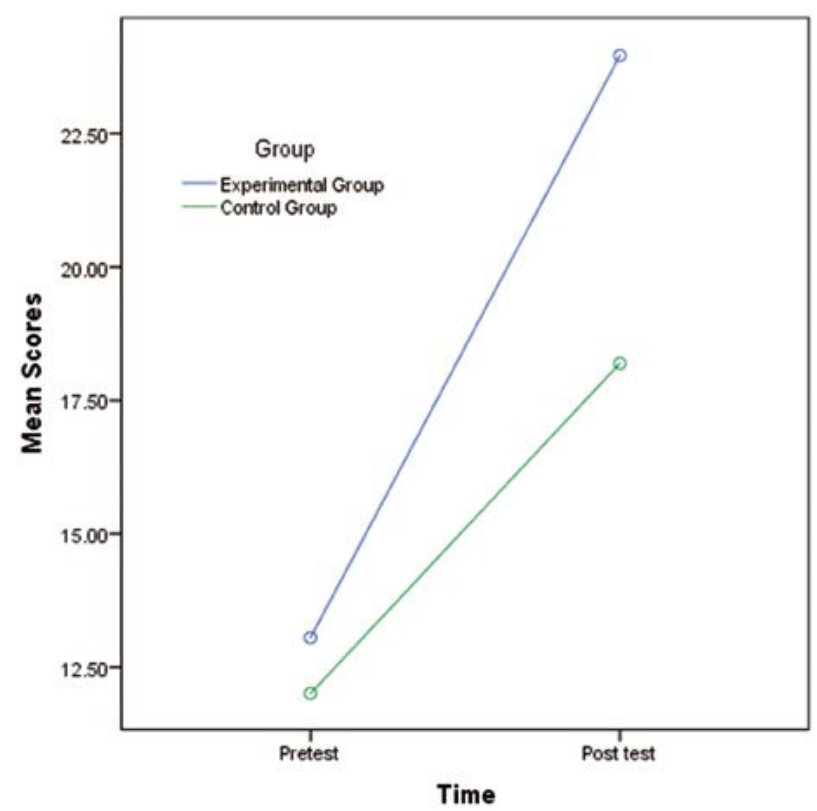

Figure 3

Pre test and pos test mean scores in academic achievement in applied math II for the experimental and control groups

\section{V.5. Refection of the classroom instructor}

The classroom instructor mentioned several improvements among students as a result of the intervention. The instructor mentioned different 
things which were categorised under five themes: persistence, cooperation, content mastery, self regulation and efficacy belief. As indicated below, students have shown significant improvement on exerting effort, cooperating among each other, mastering of the content taught, utilising time effectively and self-efficacy belief in maths.

\section{Table 7}

Refection of the classroom instructor on the intervention

\begin{tabular}{|l|l|}
\hline \multicolumn{1}{|c|}{ Theme } & \multicolumn{1}{c|}{ Element } \\
\hline Persistence/ Effort & $\begin{array}{l}\text { - Working hard in the class } \\
\text { - Attending class actively } \\
\text { - Almost all students trying to solve a given problem } \\
\text { - Participating actively } \\
\text { - Increasing effort }\end{array}$ \\
\hline Cooperation & $\begin{array}{l}\text { - Helping each other while doing exercise } \\
\text { - Trying to learn from each other }\end{array}$ \\
\hline Content mastery & $\begin{array}{l}\text { - Answering the question correctly } \\
\text { - Attaining the daily objective } \\
\text { • Doing the exercise correctly } \\
\text { - Almost all understood the topic }\end{array}$ \\
\hline Self regulation & - Utilizing the plan \\
\hline Efficacy belief & - Developing the sense of 'I can do' \\
\hline
\end{tabular}

The classroom instructor pointed out some weaknesses of the intervention packages. He mentioned some challenges from student sides like not recording the daily work on accomplishment plan, refusing to receive help by peer and also there were some resistance to work in small groups at the beginning of the experiment. The classroom instructor also added that the intervention was too much to be completed with the given period. Eventually, students were acquainted with the intervention and as result most of the problems existed at the beginning of the experiment were less apparent towards the final session of the intervention, the classroom instructor said.

\section{V.6. Qualitative findings}

Focus Group Discussion (FGD) was carried with students of the experimental group. Various questions were presented for them as described below. 
The FGD discussants were presented with questions about their experiences in Mathematics. The discussants said that they thought mathematics was a difficult subject. Some students also added that people around them told that math is a difficult subject to learn and also some of the discussants said that they love mathematics very much.

Then the discussants were asked about whether their self-efficacy in math has increased, decreased, or remained unchanged as a result of the intervention. Almost all of the discussants said that their confidence in math had improved. They added that they got confused initially; and as they went through the intervention they came to understand the procedure of the intervention. As one female student suggested students' accomplishment plan was very helpful for planning their time as per the activities covered in the class. In general, they said the intervention was important and should be extended to math $I$.

Then the discussants were also asked about whether their academic achievements have increased, decreased, or remained unchanged as a result of the intervention. Almost all the discussants said that their academic achievement had increased. They also added that the intervention was important in influencing their academic achievements as there were discussion with peer which immediately opens the door to clarify difficult contents and also timely feedback from the instructor was helpful to correct mistakes on time.

Then the discussants were also asked about the positive aspects of the intervention. The discussants said that the intervention was important to help one another and made them active. Moreover, one female student said that 'the accomplishment plan helped her a lot in attending the course attentively and budgeting her time appropriately'. They also said that they knew in detail what contents and objectives will be covered and also realized their strength and weaknesses on daily basis through the feedback given.

The discussants were also asked about the negative aspects of the intervention and things that need improvement in the future. The discussants said that it would have been better to start the intervention when the course had begun. And also it should be extended to applied math I.

Finally the discussants were invited to forward suggestions and comments about the intervention. The discussants said that the intervention should be continued as it is important to learn applied math effectively. And also they added that it should be extended to other departments in order to minimize number of students who get failed grade in applied math courses. 


\section{Discussions}

In this research, we attempted to modify the students' self-efficacy belief and academic achievements in applied math II through innovative classroom based strategy. To this end, students who received the treatment showed a significant improvement in their academic achievements consistent with the suggestions of some researchers ${ }^{47}, 48,{ }^{49}$ but inconsistent with other researcher. ${ }^{50}$

The most likely explanation for the improvement in students' academic achievements in the experimental group may be the result of the exposure to innovative classroom based strategy. Specifically, modeling, attribution feedback, positive emotional experiences, mastery experiences and goal setting whom students in the experimental group encountered could be responsible for differences in academic achievements. Attribution feedback given by teachers could change students' persistence, perseverance and perception in a way that mathematics could be mastered with effort and possibly this belief could result in improvement in academic achievements. ${ }^{51}$ Similarly, the goals setting could have a substantial impact on monitoring progress and achievement; reiterating lesson objectives could help students to organize their learning and evaluate their progress and in turn enhance students' academic achievements. ${ }^{52}$

Contrary to our findings, some researchers did not find statistically significant differences between the experimental and control groups in academic achievements. The possible reasons for inconsistent findings might be the short span of the intervention to effect academic achievements differences or the differences on the content or domain of the intervention. ${ }^{53}$

${ }^{47}$ Edgar Bresó, Wilmar B. Schaufeli, and Marisa Salanova,“Can a Self-Efficacy-Based Intervention Decrease Burnout, Increase Engagement, and Enhance Performance? A QuasiExperimental Study,' The international Journal of Higher Education Research 61, no. 4 (2010): 351, doi:10.1016/j.edurev.2010.10.003.

${ }^{48}$ Blake, M. E., Masten W. G., Henley, T. B. and Ball S. E., "Sources and Influence of Mathematics Self-Efficacy in Jamaican College Students," Caribbean Journal of Psychology 7, no. (2015): 40, Online ISSN 0799-2831.

${ }_{49}$ Naomi, B.A, "The relationship between self-efficacy and reading proficiency of firstyear students: An exploratory Study," Reading \& Writing 6, no. 1 (2015): 7, http://dx.doi. org/10.4102/ rw.v6i1.522015.

${ }^{50}$ Siegle and McCoach, "Increasing Student Mathematics Self-Efficacy through," 299.

${ }^{51}$ Zeldin, Britner and Pajares, “A Comparative Study,” 1055.

${ }^{52}$ Siegle and McCoach, "Increasing Student Mathematics Self-Efficacy," 283.

${ }^{53}$ Ibid., 299. 
On the other hand, there were no statistically significant mean differences between the experimental and the control groups on mean score of selfefficacy belief though students in experimental group scored higher on measure of self-efficacy belief in applied math II compared to students who were assigned in the control group. This finding was inconsistent with the findings of other researchers. ${ }^{54},{ }^{55}$ Majority of the interventions done with the tenet of self efficacy theory across several domains have shown the potential of the intervention strategy to influence students' self-efficacy. ${ }^{56}$

The possible explanation for the insignificant differences between the experimental and the control groups on mean score of self-efficacy beliefs on applied math II could lie on the duration of the intervention and the contents of the intervention packages. The intervention could have brought the desired change had it been implemented for a longer duration. In this research, the intervention was carried out for about four weeks due to limited resources. As a result, the intervention might not be able to bring the desired result. In this regard, the implementer of the intervention packages commented 'Had I started this on time, it would have been more fruitful'. The other explanation could be students' failure to notice and report selfefficacy belief improvements as their attention could only be on mastering the academic tasks. ${ }^{57}$

\section{Implications}

The objective of the study was to find out how an innovative classroom based strategy influences students' self-efficacy belief and academic achievements in applied math II.

The innovative classroom based strategy designed for the intervention group was effective in influencing students' academic achievement in applied math II. This finding could have a practical significance for classroom instruction. If instructors use the instructional strategies regularly such as reviewing of past lesson, communicating daily objectives, checking objectives achieved on daily basis, monitoring student progress, reinforcing student on objectives they had mastered, communicating feedback on assignment and class works, persuading students who perform poorly to

\footnotetext{
${ }^{54}$ Usher and Pajares, "Sources of Self-Efficacy in Mathematics," 100.

55 Zeldin, Britner, and Pajares, "A Comparative Study," 1054.

${ }^{56}$ Dinther, Dochy, and Segers,"Factors affecting students' self-efficacy," 104.

${ }^{57}$ Siegle and McCoach, "Increasing Student Mathematics Self-Efficacy," 305.
} 
attribute their failures to lack of effort and encouraging them to try harder on daily basis, then students' academic performance will be enhanced.

\section{Future directions and limitations}

The innovative classroom based strategy designed for promoting students' self-efficacy belief and academic achievements in applied math II at a classroom could be taken as an important innovative pedagogy. However, the applicability and generalization of the intervention package should be tested in other departments of the Technology Institute at Jimma University and other Universities with rigorous design, longer duration and improved intervention packages based on the weaknesses suggested by the implementer.

Since we observed statistically significant mean differences on academic achievements between the experimental and the control groups, the findings could have practical significance in teaching applied math. We strongly recommend that workshops and seminars should be organized at Jimma University, Technology Institute, to train instructors on how to implement the innovative classroom based strategy.

Future research works should be conducted to investigate whether students' self-efficacy belief and academic achievements in math respond better to one source of self-efficacy intervention strategy than to the other and how the four sources of self-efficacy belief interact to influence self-efficacy belief and academic achievements in math. Moreover, a research work is needed with follow up component to ascertain whether the improvement shown in academic achievement in our study is sustained or not.

Though the study came up with important findings, it has some limitations and the findings of the study should be interpreted cautiously. One of the limitations of this study could be diffusion of treatment. Students in the experimental group may share some of the tasks of the intervention to the control group which could undoubtedly affect the internal validity of the research. Similarly, we used two existing classes of students and assign one as the experimental group and the other as a control group randomly. Such assignment may introduce threat to internal validity. Moreover, the intervention which was done in classroom setting under strict supervision of the instructor may limit the external validity of the research and conducting the intervention only in two departments could also limit the generalization of the study to other settings. ${ }^{58}$

${ }^{58}$ Creswell, Educational Research, 304. 


\section{Bibliography}

Anthony, Artiny. "Academic Self-Efficacy: From Educational Theory to Instructional Practice." Journal of Perspectives on Medical Education 1, no. 2 (2012):76-85. doi:10.1007/s40037-012-0012-5.

Bandura, Albert. "Social Cognitive Theory in Cultural Context." Applied Psychology: An International Review 51, no. 2 (2002): 269-290. doi: 10.1111/14640597.0009 .

- "Perceived Self-Efficacy in Cognitive Development and Functioning, Educational Psychologist.” Educational Psychologist 28, no. 2 (1993): 117-148. doi: 10.1207/s15326985ep2802_3.

- "Social Cognitive Theory."In Annals of Child Development, edited by $R$. Vasta, Vol.6. Six theories of child development. 1-60. Greenwich: CT: JAI Press, 1989:1-60.

Boakye, N.A. "The relationship between self-efficacy and reading proficiency of first-year students: An exploratory study", Reading \& Writing 6 no. 1 (2015): 1-9. http://dx.doi.org/10.4102/ rw.v6i1.522015.

Brewer, David Shane. "The Effects of Online Homework on Achievement and Selfefficacy of College Algebra Students." Dissertations Thesis, Utah State University, 2009. Paper 407. http://digitalcommons.usu.edu/etd/407.

Creswell, J. W. Educational Research: Planning, Conducting, and Evaluating Quantitative and Qualitative Research. Boston: Pearson, 2012.

Dinther, Mart van, Dochy Filip, and Segers Mien. "Factors Affecting Students' SelfEfficacy in Higher Education." Educational Research Review 6, no. 2 (2011): 95-108. doi:10.1016/j.edurev.2010.10.003.

Edgar, Bresó, Wilmar B. Schaufeli, and Marisa Salanova. "Can a Self-EfficacyBased Intervention Decrease Burnout, Increase Engagement, and Enhance Performance? A Quasi-Experimental Study.” The International Journal of Higher Education Research 61, no. 4 (2011): 339-355. doi:10.1007/s10734010-9334-6.

Gebresilasse, A. and Abebe, K. "Gender, Self-Efficacy Belief, Sources of SelfEfficacy Associated to Academic Achievements in Applied Mathematics: The Case of First Year Engineering Students of South Western Universities of Ethiopia.” International Journal of Current Research 8, no. 05 (2016): 3039330400. http://www.journalcra.com/.

Geche Tesfaye, Jale."Learning Styles and Strategies of Ethiopian Secondary School Students in Learning Mathematics." Master Thesis, University of South Africa, 2009. http://hdl.handle.net/10500/3125.

Hassan Ahmed Elhassan Hamid, Alasmari Abdulaziz, and Ahmed,Eldood Yousif Eldood "Influences of Self-Efficacy as Predictors of Academic Achievement. A Case Study of Special Education Students- University of Jazan," International Journal of Education and Research 3 no. 3 (2015): 275-284.

Hutchison M, A., Follman D. K., Sumpter M. G., and Bodner, G M. "Factors Influencing the Self-Efficacy Beliefs of First-Year Engineering Students.” Journal 
of Engineering Education 95, no. 1 (2006): 39-47. doi: 10.1002/j.2168-9830.2006. tb00876.x.

Loo, C., and Choy, J., "Sources of Self-Efficacy Influencing Academic, Performance of Engineering Students," American Journal of Educational Research 1, no. 3 (2013): 86-92. DOI:10.12691/education

Marion E. Blake, William G. Masten, Tracy B. Henley, Steven E. Ball, "Sources and Influence of Mathematics Self-Efficacy in Jamaican College Students" Caribbean Journal of Psychology 7, no. (2015): 24-42, Online ISSN 0799-2831

May, Diana, K., "Mathematics Self-Efficacy and Anxiety Questionnaire.” PhD Dissertation University of Georgia, 2009. https://getd.libs.uga.edu/pdfs/may_ diana_k_200908_phd.pdf.

Meera and Jumana "Self-Efficacy And Academic Performance In English" Imperial Journal of Interdisciplinary Research, 2, no. 2 (2016): 79-83, ISSN: 2454-1362, http://www .onlinejournal.in

Mwamwenda T. S. "Self-Efficacy and Performance in Mathematics at An African University." The Journal of Independent Teaching and Learning 4 (2009): 2328. Long Island University, Global College, Durban, http://www.iie.ac.za/.

Pajares, Frank and Miller M. David. "Role of Self-Efficacy and Self-Concept Beliefs in Mathematical Problem Solving: A Path Analysis." Journal of Educational Psychology 86, no. 2 (1994):193- 203. http://www.cimm.ucr.ac.cr/.

Siegle, D., and McCoach, D. B. "Increasing Student Mathematics Self-Efficacy through Teacher." Journal of Advanced Academics Training 18, no. 2 (2007): 278-312. doi: 10.4219/jaa-2007-353.

Schoenfeld, A. H. "Learning to think mathematically: Problem solving, Metacognition, and Sense-making in Mathematics." In Handbookfor Research on Mathematics Teaching and Learning, edited by D. Grouws, 334-370.New York: MacMillan, 1992.

Sewell, Alison, and St George Alison. "Developing efficacy beliefs in the classroom." Journal of Educational Enquiry 1, no. 2 (2000): 58-71.

Usher, Ellen L., and Pajares Frank."Sources of Self-efficacy in Mathematics: A Validation Study." Contemporary Educational Psychology 34, no. 1 (2009): 8991. doi:10.1016/j.cedpsych.2008.09.002.

Usher, E. L., and Pajares, F. "Sources of Academic and Self-Regulatory Efficacy Beliefs of Entering Middle School Students." Contemporary Educational Psychology 31 (2006): 125-141. doi:10.1016/j.cedpsych.2005.03.002.

Zeldin, A. L., Britner S. L., and Pajares, F. "A Comparative Study of the SelfEfficacy of Successful Men and Women in Mathematics, Science And Technology Careers." Journal of Research in Science and Teaching 45, no. 9 (2008): 1036-1058. doi: 10.1002/tea.20195.

Zimmerman B. J. "Self-Efficacy: An Essential Motive to Learn." Contemporary Educational Psychology 25 (2000): 82-91. doi:10.1006/ceps.1999.1016. 


\section{About the Authors}

KINDE GETACHEW ABEBE (kinde.getachew@ju.edu.et), MA in Educational Psychology, is associate professor in the Psychology Department at the Jimma University (Ethiopia). He is currently involved in the teaching at the undergraduate and post-graduate students and he is the Coordinator of Academic Quality Assurance at the College of Education and Behavioural Sciences. His principal field of research is behaviour in school and health settings. He has extensive experience in teaching, research, and consultancy services.

ASFAWOSSEN BIRHANE (basfawesen111@gmail.com), MSc. in Mathematics, is assistant professor in the Mathematics Department at the Jimma University (Ethiopia) where he teaches undergraduate and post-graduate courses. His main research interest is in Mathematics education. He also has extensive experience in teaching, research, and consultancy services. 


\section{Improving students' self-efficacy and academic performance in Applied Mathematics through innovative classroom-based strategy at Jimma University, Ethiopia}

Kinde Getachew and Asfawossen Birhane*

\section{Copyright}

Copyright for this article is retained by the Publisher. It is an Open Access material that is free for download, distribution, and or reuse in any medium only for non-commercial purposes; provided any applicable legislation is respected, the original work is properly cited, and any changes to the original are clearly indicated. 